\title{
Kajian Biblika Tentang Yesus Membawa Pemisahan Menurut Injil Matius 10:34-42 Dan Implikasi Praktis Bagi Orang Kristen Masa Kini
}

\author{
Tomi Jepisa, Peniel C. D. Maiaweng
}

\begin{abstract}
Abstrak
Menyikapi tentang pernyataan Yesus yang menyatakan bahwa "Aku datang untuk memisahkan" dan implikasinya bagi kehidupan orang Kristen pada masa kini menurut Matius 10:34-42. Pernyataan ini yang menjadi latar belakang pembahasan yang akan penulis bahas, yang berkaitan dengan kehidupan orang Kristen pada masa kini. Injil Matius salah satu kitab Injil yang membahas mengenai ucapan Yesus yang sepertinya memiliki kontradiksi jika di lihat dari sudut pandang tujuan kedatangan Yesus ke bumi. Sudut pandang ini bisa menimbulkan bahaya, jika tujuan kedatangan Yesus di pemahami sebagai pembawa konflik dan pemisahan, dalam teks yang dibahasa Matius memang menuliskan demikian, tentang pernyataan Yesus yang menyatakan, "Aku atang membawa bukan membawa damai, melainkan pedang" dan "pemisahan".

Kesimpulanya ialah ini bukanlah tujuan ke datangan Yesus, tetapi konflik dan pemisahan yang terjadi adalah akibat penolakan dan perbedaan pilihan oleh manusia terhadap kedatangan Yesus yang membawa Injil kerajaan Allah. Dalam penelitian Matius 10:34-42, penulis menggunakan prinsip-prinsip penafsiran ilmu Hermenetik secara umum dan studi kepustakaan, dengan menggunakan buku-buku tafsiran dan pendapat para ahli tentang makna pernyataan Yesus.
\end{abstract}

Kata kunci: Yesus, pemisahan, salib, mengasihi,upah.

\section{Pendahuluan}

\section{Latar Belakang Masalah}

Dalam pengajaran-Nya, Tuhan Yesus memiliki cara yang berbeda dengan guru-guru dan ahli-ahli Taurat pada masa itu yang membedakan Yesus dengan para ahli Taurat ialah bahwa Tuhan Yesus mengajar dengan kuasa (Matius 7:29) dan apa yang Yesus ajarkan, itu semua sesuai dengan apa yang Ia lakukan. Selain berbeda, Tuhan Yesus juga sangat kreatif dalam mengajarkan firman-Nya. Kreativitas tersebut dapat terlihat ketika Dia menyampaikan suatu pengajaran dengan menggunakan media sekitar, seperti: "bunga bakung di ladang" Matius 6:28. Selain itu, Tuhan Yesus juga terkenal sangat cerdas dan cakap mengajar. Namun sebagai guru yang baik, Tuhan Yesus tidak hanya berbeda dan kreatif dalam pengajaran-Nya, tetapi Dia juga dikenal sebagai guru yang tegas dan keras dalam pengajaranNya, seperti salah satu contoh, pernyataan keras yang Ia sampaikan kepada para murid dalam Injil Matius 10:34-42. Sekilas tampak pernyataan Yesus di sini susah untuk dipahami, karena 
sepertinya kontradiksi dengan inti pengajaran-Nya tentang kasih, perdamaian, dan pengampunan, Yesus yang adalah Raja Damai, menyatakan bahwa Ia datang bukan untuk membawa Damai melainkan pedang dan pemisahan.

Oleh sebab itu untuk memahami pernyataan Yesus dalam teks ini, penulis ingin melihat beberapa pandangan para panfsir tentang teks Matius 10:34-42. de Heer, dalam bukunya, Tafsiran Injil Matius pasal 1-22 mengatakan:

Dengan sedikit heran kita membaca bahwa Yesus datang, "bukan untuk membawa damai, melainkan pedang". Tetapi ucapan ini hanya berarti bahwa "pedang" adalah akibat kedantangan Yesus ke dunia. Sebenarnya Ia ingin menciptakan perdamaian di antara manusia dan sesamanya; tetapi tak dapat tidak pemberitaan Injil dalam dunia yang berdosa ini akan menimbulkan perang dan perselisihan. ${ }^{1}$

Dalam penjelasannya, penfasir berbicara mengacu kepada konteks di mana dampak dari pemberitaan Injil Kristus, yang akan menyebabkan perang dan perselisihan. Penafsir menegaskan bahwa pemisahan dan konflik yang terjadi bukanlah tujuan kedatangan Yesus ke bumi, melainkan semata-mata disebabkan oleh berbagai respons manusia terhadap Injil. Pendapat ini ditegaskan kembali dalam Tefsiran Alkitab Masa Kini Matius-Wahyu, disitu mengatakan bahwa memang ke datangan Yesus ke dunia adalah sebagai Raja damai, yang tujuan-Nya adalah membawa damai di tengah-tengah manusia, tetapi apa yang terjadi sebaliknya malah kedatangan Yesus menyebabkan terjadinya pertentangan yang di simbolkan dengan "pedang" pertentang itu akan terjadi antara orang yang percaya kepada Injil dengan orang yang menolak Injil. ${ }^{2}$ Pernyataan ini menegaskan kembali pendapat de Heer dalam tafsirannya yang mengatakan terjadinya pertentangan, pemisahan, konflik dan perselisihan bukanlah tujuan kedatangan Yesus. Pendapat lain yang di ungkapkan oleh, Leon Morris, dalam Tafsiran Injil Matius yang mengatakan, bahwa pernyataan Yesus sungguh mengejutkan bagi para pengikut-Nya pada saat itu, mengapa? Karena nada pengajaran Yesus secara umum dan tindakan-Nya seakan menunjukkan akan terjadinya damai di bumi. Tetapi apa yang Yesus nyatakan malah hal sebaliknya, bahwa Ia datang membawa pedang dan pemisahan yang menjadi suatu simbol konflik, pernyataan ini menunjukkan bahwa, mengikut sang Raja damai, akan mengalami perpecahan dan konflik, yang di gambarkan dengan pedang. ${ }^{3}$ sekali lagi bahwa konflik dan pemisahan yang terjadi dalam keluarga bukanlah tujuan kedatangan Yesus ke bumi.

Ada perbedaan pandangan tentang makna "pedang" dalam teks Matius10:34-36, jika sebelumnya makna "pedang" adalah simbol konflik, perselsihan dan pemisahan dalam keluarga. Tetapi Matthew Henry, dalam Tafsiran Injil Matius Pasal 1-14 menyatakan bahwa makna ungkapan "pedang" di sini di artikan Yesus datang memberikan Pedang Roh, yaitu Firman Allah, kata ini dipakai oleh Paulus juga dalam Efesus 6:17, dalam suratnya Paulus menyatakan bahwa pedang Roh itulah firman Allah, yang digunakan untuk melawan tipu muslihat iblis. Jadi dalam tafsirannya, Matthew Henry menekankan bahwa "pedang" itu adalah Firman Allah yang diberikan oleh Allah kepada para murid untuk dipergunakan oleh mereka untuk melawan musuh. ${ }^{4}$ Sepertinya ada perbedaan penekanan dalam satu teks yang

\footnotetext{
${ }^{1}$ J. J. de Heer, Tafsiran Injil Matius Pasal 1-22 (Jakarta: BPK Gunung Mulia, 1952), 199.

${ }^{2}$ Tafsiran Alkitab Masa Kini Matius-Wahyu (Jakarta: BPK Gunung Mulia, 1983), 88.

${ }^{3}$ Leon Morris, Tafsiran Injil Matius (Surabaya: Momentum, 2016), 274.

${ }^{4}$ Matthew Henry, Injil Matius 1-14 (Surabaya: Mementum, 2014), 469.
} 
sama dari kedua pandangan ini. Selain itu, France, dalam bukunya, Yesus Sang Radikal, mengatakan bahwa, kelompok para teolog liberal pada abad yang lalu melukiskan tentang Yesus sebagai seorang yang amat menyokong perdamaian dan keadilan social, dan dalam tulisannya, France mengatakan suatu pernyataan bahwa sebagian orang dibesarkan dengan ajaran tentang Yesus yang lemah lembut, dan sahabat anak-anak, yang tidak mau marah atau bertindak tegas. ${ }^{5}$

Dan pada halaman sebelumnya, France, menuliskan bahwa Yesus tidak bisa menyelubungi arti kata-kata-Nya. Contoh seperti ungkapan yang Yesus ungkapkan dalam Matius 10:34-36, ungkapan tersebut berbunyi, "Janganlah menyangka bahwa aku datang membawa perdamaian ke muka bumi. Aku tidak membawa perdamaian, tetapi perlawanan." Intinya pokok yang Yesus sampaikan dalam ungkapan-Nya adalah bahwa, "Ia seorang pemisah, dan pengganggu perdamaian." 6

Jadi latar belakang masalahnya ialah jika pemisahan, konflik dan pertentangan yang dimaksud dalam teks ini dipandang sebagai tujuan kedatangan Yesus, maka hal itu bisa menimbulkan kesalahpahaman yang fatal tentang teks Matius 10:34-42.

\section{Pokok Masalah}

Berdasarkan latar belakang masalah diatas, maka yang menjdi pokok masalah dalam karya tulis ini adalah:

Pertama, apa makna Yesus datang membawa pemisahan berdasarkan konteks teks Matius 10:34-42.

Kedua, apa implikasi Yesus datang membawa pemisahan bagi orang-orang Kristen masa kini menurut Matius 10:34-42.

\section{Tujuan Penulisan}

Pertama, untuk mengembangkan pokok pikiran tentang kajian Biblika Yesus datang membawa pemisahan menurut Matius 10:34-42.

Kedua, untuk mengimplementasikan tentang Yesus membawa pemisahan menurut Matius 10:34-42 bagi kehidupan orang-orang Kristen masa kini.

\section{Manfaat Penulisan}

Ada pun maanfaat penulisan skripsi ini adalah sebagai berikut:

Pertama, untuk menjadi pedoman pengajaran bagi penulis tentang Yesus membawa pemisahan di pelayanan.

Kedua, untuk membangun teologi biblical tentang Yesus membawa pemisahan secara khusus di Sekolah Tinggi Theologia Jaffray Makassar dan secara umum di Sekolah Tinggi Theologi di Indonesia.

Ketiga, untuk memenuhi salah satu persyaratan akademik untuk mencapai gelar Sarjana Teologi di Sekolah Tinggi Teologi Jaffray Makassar.

\footnotetext{
${ }^{5}$ R. T. France, Yesus Sang Radikal (Jakarta: BPK Gunung Mulia, 2004), 14.
}

${ }^{6}$ Ibid., 13. 


\section{Batasan Penelitian}

Penulis membatasi penelitian ini hanya berfokus pada pembahasan tentang Yesus datang membawa pemisahan berdasarkan Matius 10:34-42.

\section{Kesimpulan}

Berdasarkan hasil pembahasan penulis mengenai Kajian Biblika tentang Yesus membawa pemisahan berdasarkan Matius 10:34-42, maka penulis menyimpulkannya sebagai berikut:

Pertama, kedatangan Yesus ke bumi yang menyebabkan terjadinya pemisahan, konflik dan percpecahan sesungguhnya perpecahan dan pemisahan bukanlah tujuan dari kedatangan Yesus, melainkan dampak atau akibat yang timbul oleh karena perbedaan respon manusia terhadap Injil yang Yesus sampaikan. Ada manusia yang menerima dan ada juga yang menolak, perbedaan pilihan tersebutlah yang mengakibatkan terjadinya pemisahan antara orang percaya dengan orang yang tidak percaya. Jadi intinya Yesus datang bukan untuk memecah belah keluarga, sekali lagi tujuan kedatangan Yesus ialah untuk melepaskan manusia dari dosa dan jerat iblis, sehingga timbulah perlawanan atau perang dengan orang yang menolak Dia yaitu mereka yang menjadi sekutu roh jahat.

Kedua, menetapkan pilihan mengasihi Yesus lebih dari keluarga, memerlukan sikap hati yang tulus dan komitmen yang kuat dengan mata yang tertuju hanya kepada Allah. sebagai orang Kristen, untuk menjadi seorang pengikut yang layak menurut Yesus, perlu pengorbanan dan kerendahan hati untuk menundukkan diri di hadapan Allah. menempatkan Kristus sebagai yang pertama dan terutama dalam hidup, bukanlah perkara gampang, dewasa ini banyak hal yang bisa menggeser posisi utama Allah dalam kehidupan orang Kristen pada masa kini, seperti: keluarga, harta kekayaan, kekuatiran, kepentingan pribadi. Oleh sebab sebagai orang Kristen dengan memiliki kasih yang tulus akan Allah. karena jika Allah telah menempati posisi yang utama dalam kehidupan manusia, maka tidak ada hal lain yang dapat menggeser posisi Allah dalam hatinya, sebab ia sadar bahwa hanya oleh kasih karunia Allahlah ia di selamatkan (Ef. 2:1-10)

Ketiga, pemisahan yang tiada batasnya akan di alami oleh orang-orang yang tidak siap untuk berkorban, memikul salib, menyangkal diri dan mengikut Krisus. Tetapi mereka hanya mementingkan diri sendiri, mengabaikan Kristus dengan memilih jalan hidupnya sendiri tanpa peduli akan Firman Tuhan. Maka Allah yang berdaulat atas hidup manusia menyatakan, bahwa orang yang hidupnya demikian, akan kehilangan nyawanya untuk selama-lamanya dan berada dalam kekekalan hukuman yang mengerikan. (Mat. 10:38-39). Orang-orang seperti itulah yang akan dipisahkan oleh Allah dari orang-orang percaya yang setia menjadi pengikut Kristus dalam situasi kondisi apa pun.

Keempat, orang yang memberikan respon positif akan kedatangan Kristus, dengan utusan Allah, dan rela memberi tumpangan serta memiliki kerendahan hati untuk melayani Kristus dan utusan-Nya. Maka Allah akan memberkati mereka dan mereka berhak untuk menerima upah atau balasan dari Allah sesuai dengan kehendak-Nya. Allah tidak menuntut berapa nilai dan jumlah yang orang-orang perbuat bagi-Nya, sebab ukuran Allah berbeda dengan ukuran manusia. Tetapi dalam hal balasan tentu Allah akan memberikan balasan atau upah yang setimpal dengan apa yang telah mereka perbuat bagi-Nya. Jadi upah yang Allah sediakan bagi orang-orang Kristen yang dengan setia menjadi pengikut dan melayani Dia, 
bukanlah dalam bentuk materi atau uang, melainkan berkat anugerah keselamatan yang kekal di dalam Kristus Yesus (Mat. 19:27-29).

\section{Kepustakaan}

Brake, Andrew. Keunggulan Kristus Dan Kerajaan Allah Refleksi-refleksi dari Matius 9-20. Makassar: Sekolah Tinggi Theologia Jaffray, 2018.

Barclay, Wiliam. Pendalaman Alkitab setiap hari Matius 1-10. Jakarta: BPK Gunung Mulia, 1991.

Bruce, F. F. Ucapan-Ucapan Yesus yang Sulit. Malang: Literatur Saat, 2015.

Carlton, Matthew E. Terjemahan Khusus Penerjemahan dan Pendalaman Alkitab Injil Matius. Jakarta: Kartidaya, 2002.

Carson, D. A. \& Douglas J. Moo. An Introduction To New Testament. Malang: Gandum Mas, 2016.

de Heer, J. J. Tafsiran Injil Matius Pasal 1-22. Jakarta: BPK Gunung Mulia, 1952.

France, R. T. Yesus Sang Radikal. Jakarta: BPK Gunung Mulia, 2004.

Fee, Gordon D. dan Douglas Stuart. Hermeneutik Bagaimana Manfsirkan Firman Tuhan Dengan Tepat. Malang: Gandum Mas, 2000.

Guthrie, Donald. Pengantar Perjanjian Baru volume 1. Surabay: Momentum, 2010.

Gering, Howard M. Analisa Alkitab. Jakarta: Yayasan Pekabaran Injil Immanuel, 1995.

Guthrie, D. et al. Tafsiran Alkitab Masa Kini Matius-Wahyu. Jakarta: BPK Gunung Mulia, 1983.

Henry, Matthew. Injil Matius 1-14. Surabaya: Momentum, 2014.

Kriswanta, Gregorius. Menjadi Murid Kristus Itu Giaman Sih?. Yogyakarta: Kanisius, 2009.

Leks, Stefen. Percakapan Tentang Mengikut Yesus. Yogyakarta: Kanisius, 1988.

Lembaga Biblika Indonesia. Tafsiran Perjanjian Baru Injil Matius. Yogyakarta: Yayasan Kanisius, 1981.

Leks, Stefan. Tafsiran Sinoptik Injil Matius. Yogyakarta: Karnisius, 2003.

Lele, Flavius Aldorio, Robi Panggarra, "Makna Tujuh Ungkapan Yesus di Salib Bagi Orang Percaya." Jurnal Jaffray 13, no. 2 (Oktober 2015): 285-316.

Morris Leon. Tafsiran Injil Matius. Surabaya: Momentum, 2016.

Pratt, Richard L. Dirancang Bagi Kemuliaan. Surabaya: Momentum, 2002.

Pau, E. G. Willem. Bara Kasih 2008. Yogyakarta: Percetakan Pohon Cahaya, 2017.

Pfeiffer, F. Charles \& Everet F. Harrison. The Wycliffe Bible Commentary, Volume 3 MatiusWahyu. Malang: Gandum Mas, 2013.

Saidi, Acep, Iwan. "Hermeneutika sebuah cara untuk memahami teks." Jurnal Sosioteknologi 7 no.13 (April 2008): 376-382. Diakses 10 April 2018. http://journals.itb.ac.id/index.php/sostek/article/view/996/605.

Sutanto, Hasan. Hermeneutik Prinsip dan Metode Penafsiran Alkitab. Malang: Seminari Alkitab Asia Tenggara, 1998.

Simamora, Daniel. The Bible Who's Who a Biblical Biography. Bandung: Cipta Olah Pustaka Publishing House, 2016. 
Stott, John, The Radcal Disciple (Murid Yang Radikal). Surabaya: Literatur Perkantas Jawa Timur, 2010.

Wiersbe, Warren W. Loyal Dalam Kristus. Bandung: Kalam Hidup, 2012.

Wijaya, Hengki. Analisis Data Kualitatif. Makassar: Sekolah Tinggi Theologia Jaffray, 2018. 